\title{
It's all about the structure
}

\author{
For more than 20 years, Brian Kobilka worked to create a portrait \\ of a key cell receptor. Sometimes, the slow, steady approach wins.
}

\section{BY LIZZIE BUCHEN}

B rian Kobilka was exhausted when he stepped off the 12-hour red-eye flight from China to San Francisco, California, last May. But after a quick nap at home, he headed straight back to the airport and crammed his long frame into another plane, this time bound for Chicago, Illinois. Once there, he drove to the Advanced Photon Source at Argonne National Laboratory, a source of powerful X-ray beams used for analysing protein structures. Kobilka, a biochemist at Stanford University in California, was desperate to see the latest data from his lab's effort to make the first atomic-scale, three-dimensional image of a key cell-surface receptor locked with its protein partner. The image marked the last leg of an intellectual journey that he had started some 20 years before.

Nearly every function of the human body, from sight and smell to heart rate and neuronal communication, depends on G-protein-coupled receptors (GPCRs). Lodged in the fatty membranes that surround cells, they detect hormones, odours, chemical neurotransmitters and other signals outside the cell, and then convey their messages to the interior by activating one of several types of $\mathrm{G}$ protein. The $\mathrm{G}$ protein, in turn, triggers a plethora of other events. The receptors make up one of the largest families of human proteins and are the targets of one-third to one-half of drugs. Working out their atomic structure will help researchers to understand how this central cellular-communication system works, and could help drug-makers to design more effective treatments.

The structure and workings of GPCRs have been overriding obsessions of Kobilka for most of his professional life. For much of this, he had little company, as the proteins were widely considered too complex and unwieldy to be stabilized as crystals, a prerequisite for structural
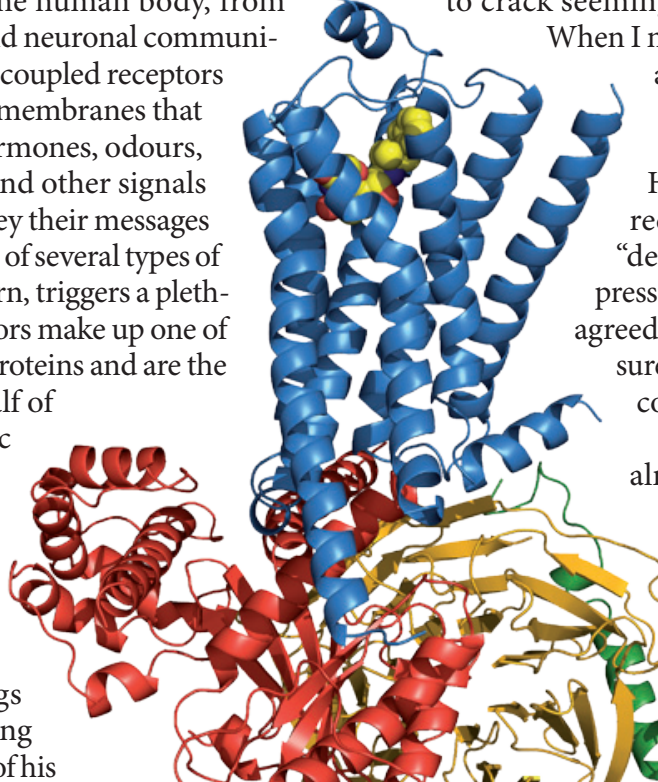

analysis by X-ray crystallography. But his determination has finally started to pay off. In 2007, his team solved the first high-resolution structure of a GPCR that binds to a hormone $\mathrm{e}^{1-3}$; in January this year he did the same for the receptor poised to activate its G-protein ${ }^{4}$; and last month, he published the results from Chicago, the first structure of any GPCR in the act of turning on its G protein ${ }^{5}$.

The latest accomplishment has many in the field buzzing about a Nobel prize. "But if they do give it to him, it'll be the devil to get him to Stockholm," says Henry Bourne, a professor emeritus at the University of California, San Francisco, who worked on $G$ proteins and has known Kobilka since the 1980s. Kobilka loathes the limelight, and is renowned as much for his shy modesty as his ability to crack seemingly impossible protein structures. When I met Kobilka at his Stanford office, he accepted a quick handshake, averting his eyes, and reluctantly offered me a seat across from him at his desk. He stared anxiously at the glowing red light on my voice recorder. $\mathrm{He}$ is "desperately fearful" of talking to the press, he says, his voice breaking, and only agreed to talk because he "wanted to make sure that the contributions of my lab and collaborators are recognized".

He is so fearful, in fact, that it is almost impossible to draw much out from him. When asked why he is so captivated by GPCRs, Kobilka struggles for an answer. "I'm just inherently fascinated by these proteins. I don't know. I just want to know how they work," he says. The only time he becomes animated is when describing the conformation of the receptor gripping its $\mathrm{G}$ protein.

"It's a fantastic structure," he says, a grin across his face. "It's just amazA fine figure: a molecular view of a G-protein-coupled receptor (blue) turned on by a signalling molecule (yellow spheres, top) and activating a $\mathrm{G}$ protein (red, gold and green). ing. I really enjoy talking about it."

Bourne says that "Brian is a fascinating character. He's so driven, and $>$ 
enormously intense. But you don't get any feeling of nor is there any - self-aggrandizing, pushiness, showoffiness. There is absolutely none of that. It's quite refreshing and rare."

Perhaps Kobilka's rare reticence and determination are exactly what make him so well-suited for the task of protein crystallization - a pursuit in which a complete atomic structure is the finish line, and there are few intermediate rewards. "What he did was, step by step, sneak up on it to make it work," says Bourne.

\section{BAKING TO BIOLOGY}

Kobilka is from a small, rural community in central Minnesota. His grandfather and father were bakers; his mother decorated the cakes. Kobilka studied biology and chemistry at the University of Minnesota in Duluth, where he met his future wife, Tong Sun Thian, in biology class. "He always topped the curve," she says. "But he was also so modest and quiet, you'd never know."

Kobilka got his first taste of research when he and Tong Sun worked in a developmental biology lab at the university, and built a tissue-culture hood for the lab using scrap heavy plastic from his father's bakery. He enjoyed research, but went to medical school anyway - in rural Minnesota, he says, people who were interested in biology became doctors. Studying at Yale University in New Haven, Connecticut, Kobilka developed an interest in intensive-care medicine and the drugs used in life-or-death situations that act on GPCRs - particularly the receptors for adrenaline and noradrenaline, which open the airways and boost heart rate.

In 1984, after his residency, Kobilka applied for a fellowship with Robert Lefkowitz at Duke University in Durham, North Carolina. It was the premier lab studying receptors for adrenaline, which had become a model system for all hormone receptors. When Kobilka joined, the lab was just starting to think about how to clone the gene for the $\beta_{2}$-adrenergic receptor $\left(\beta_{2} \mathrm{AR}\right)$ and determine its genetic sequence. But the receptor was produced in such small amounts that the team was only able to collect enough protein to work out a few scraps of its likely genetic sequence. Kobilka then displayed "the first of many flashes of technological innovation", says Lefkowitz: he decided to construct a library of mammalian genomic sequences and screen it with the scraps of sequences they had. This would pull out longer clones that could be pieced together to reveal the full sequence.

The plan worked. And when the team stitched together the receptor sequence ${ }^{6}$, it held a surprise: several strings of amino acids that are typically found in cell membranes showed that the receptor snaked through the membrane seven times. It was just like rhodopsin, the light-detecting receptor in the retina that was also known to activate a $G$ protein. At the time, there was no reason to think that these receptors were going to look the same - especially when one was turned on by light, and the other by a hormone.

"It was a real eureka moment," recalls Lefkowitz. At the time, about 30 proteins were known to turn on G proteins. "We realized, oh my god, they're all going to look like this. It's a whole family!"

That family became known as seven-transmembrane receptors, or GPCRs - and is now known to have nearly 800 members in humans. Kobilka describes the watershed cloning project with humility. "It was exciting just to be involved," he says. "It was the result of a lot of heroic work by the Lefkowitz lab."

Sometimes that self-effacement has

\section{DNATURE.COM}

Read more about GPCRs:

go.nature.com/rwhgqh

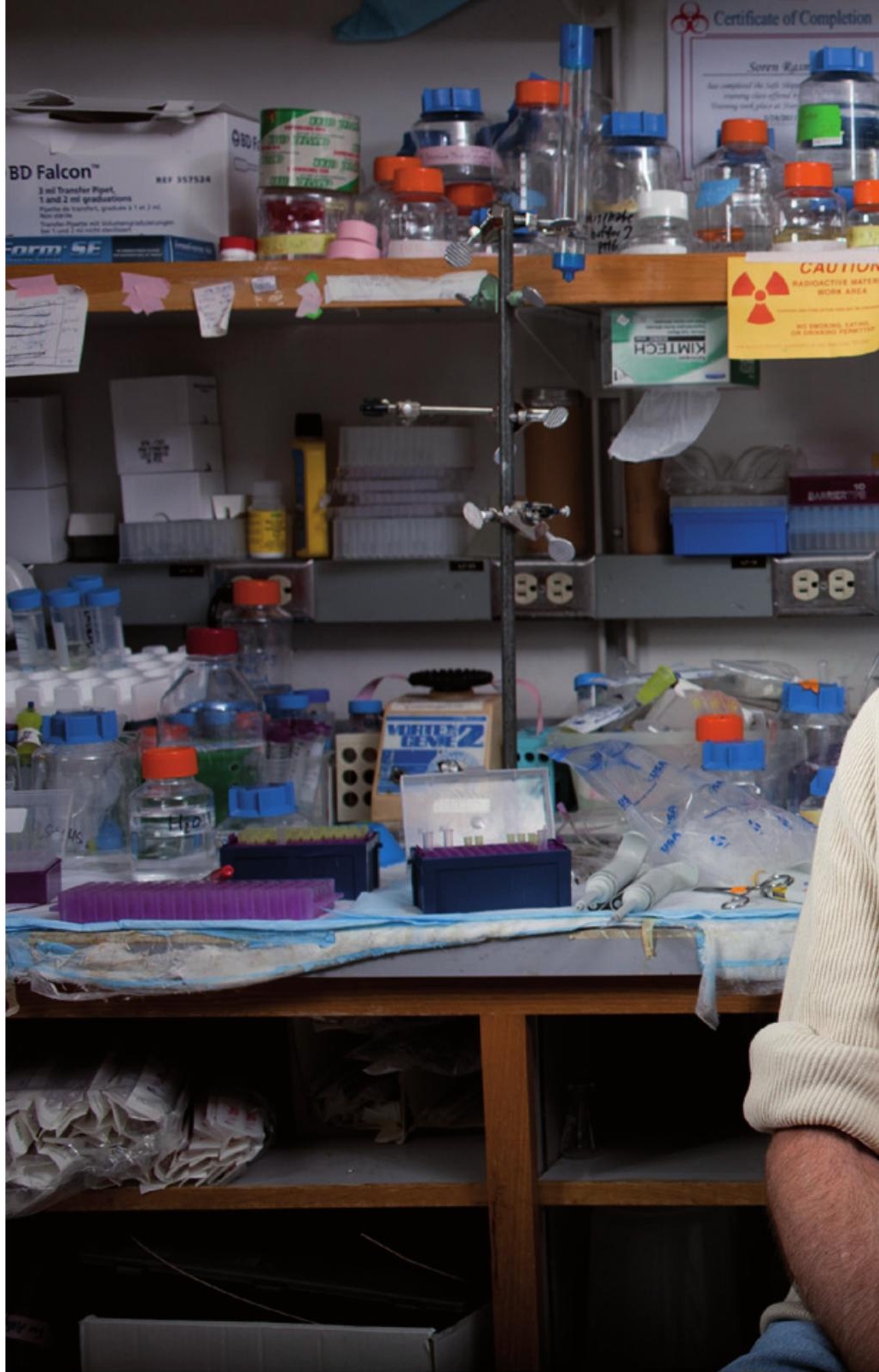

held Kobilka back. After he left Duke, he was interviewed for a faculty position in the pharmacology department at the University of California, San Francisco. "We had him and another guy," says Bourne, who was then head of the department. "It was very clear to everyone that Brian was smart, no question. But he didn't sparkle in the slightest. He was this shy, pale, Scandinavian-looking guy. I thought, who is this guy? He's very strange, so modest, so quiet."

The other guy got the job, and Stanford snapped up Kobilka, says Bourne. "We should have hired both of them."

After his success with $\beta_{2} \mathrm{AR}$, Kobilka was hooked. He wanted to see what the receptor looked like in three dimensions using X-ray crystallography, in which a beam of X-rays is fired at a protein crystal and the resultant diffraction pattern is used to reveal the arrangement of its atoms. It was an audacious goal. To produce an intelligible X-ray diffraction pattern, Kobilka first needed to crystallize the receptor - a formidable process of packing millions of identical copies of protein so tightly that they form a solid that looks like a microscopic shard of glass. Working out the conditions that will allow a protein to crystallize can take years, and membrane proteins such as GPCRs are the hardest of all: they must be coaxed out of the membrane intact, but it is the membrane that holds them in shape. GPCRs are also constantly shifting into various states, and most are expressed in very low quantities. To collect enough protein, Kobilka 


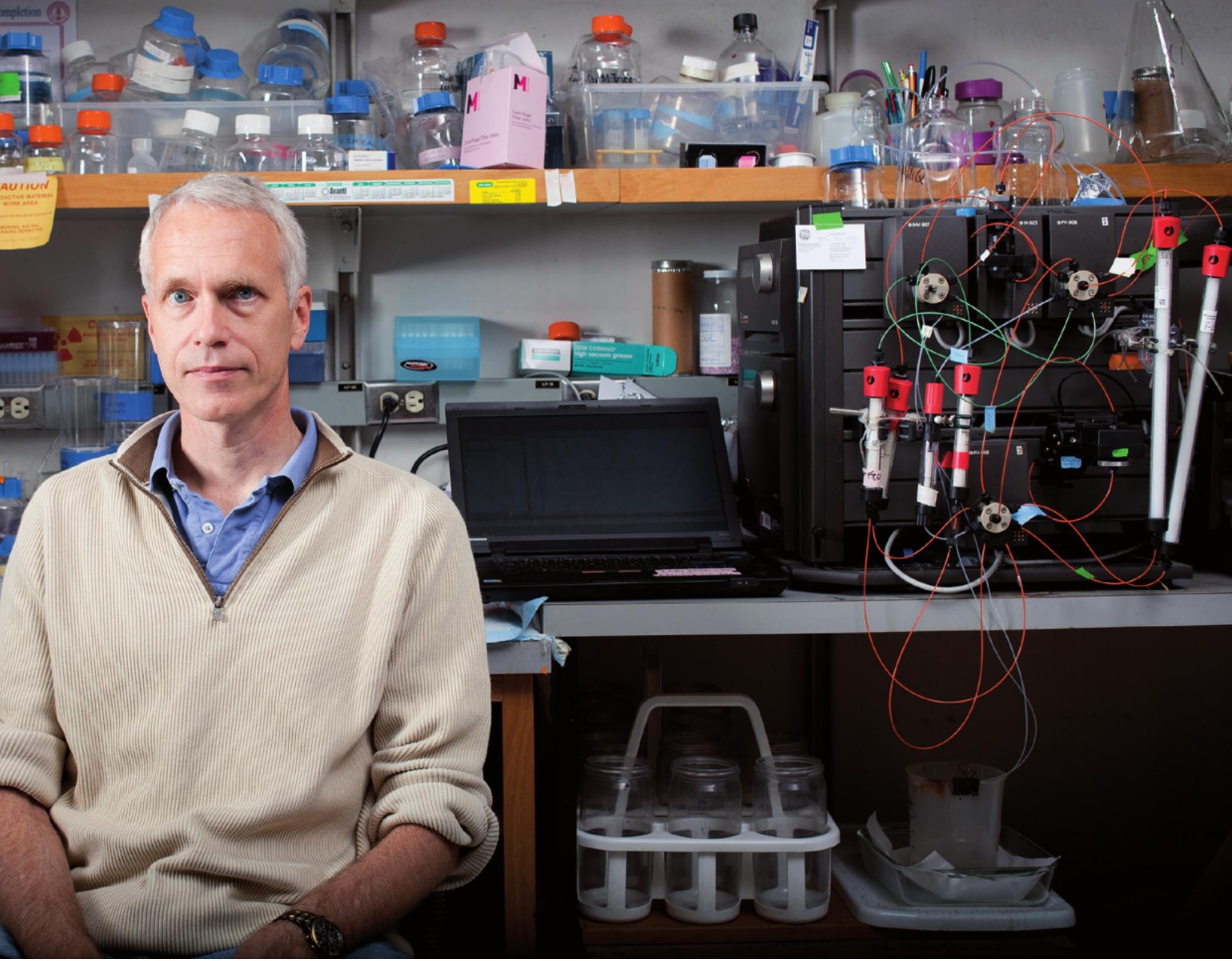

Brian Kobilka is "inherently fascinated" with G-protein-coupled receptors and has single-mindedly sought their structures.

would need to express the $\beta_{2}$ AR at about $100-1,000$ times the levels at which it is normally produced in a cell. At that time, no one was close to crystallizing a GPCR and few were trying.

Crystallizing the receptor became Kobilka's pet project because he thought it was too high risk for a postdoc or graduate student. "We used to joke that he'd come running into the lab from teaching or a meeting with a column in his hand, trying to do a binding assay to see if his latest purification had worked before he went home," says Mark von Zastrow, one of Kobilka's first postdocs, who now studies GPCR trafficking at the University of California, San Francisco. Kobilka had reason to rush through the workday - he had two young children at home, Tong Sun was at medical school and they had a "tremendous" mortgage. To make ends meet, he moonlighted as a doctor in the emergency department atn weekends. Von Zastrow recalls poking fun at Kobilka for his seemingly futile crystallography project. "He told us, 'You'll see. The crystals are going to be so big, I'm going to make a ring for Tong Sun out of them."

As the years rolled by, Kobilka's lab was carrying out various biochemistry and biophysics experiments aimed at getting to know the $\beta_{2}$ AR more intimately, and he was inching forwards in expressing and purifying the protein. But he wasn't noticeably closer to getting the structure. "People viewed what he was doing as dotting i's and crossing t's," says Bourne. "And for a while it was sort of that. He wasn't getting published in fancy journals." The team showed that GPCRs have big, floppy loops inside and outside the cell, and that the receptor writhes and squirms, adopting a variety of levels of activation ${ }^{7}$. The work only made crystallization look more impossible.

In the meantime, another GPCR crystallography effort raced ahead. In 2000, Krzysztof Palczewski and his postdoc Tetsuji Okada, then at the University of Washington in Seattle, published the crystal structure of rhodopsin, the light-sensing GPCR in the retina ${ }^{8}$. It was a significant accomplishment, but of little help to Kobilka. Rhodopsin is plentiful - a bucketful of cow eyes from the slaughterhouse gives enough pure protein for crystallography. It is also simpler and more stable than other GPCRs, and its structure was thought to be different.

In 2001, Kobilka got disheartening news. His main funding, from the Howard Hughes Medical Institute in Chevy Chase, Maryland, would not be renewed after it ran out in 2003. His lab began to struggle financially, and went "deep into the red" to support his expensive crystallization crusade. "I don't think I ever considered giving up," says Kobilka. "I admit that it was frustrating at times, but I enjoyed the challenge and I wanted to know the answer." Kobilka says that one of his friends "best described my 
persistence as 'irrational optimism"'.

Finally, in late 2004, his group managed to grow tiny crystals - too small to be analysed at Stanford's synchrotron facility. Gebhard Schertler, a crystallographer then at the Medical Research Council Laboratory of Molecular Biology in Cambridge, UK, suggested that Kobilka take his samples to the European Synchrotron Radiation Facility (ESRF) in Grenoble, France, which had the tightly focused beamline needed to analyse such small crystals. "We were running out of money all the time," says Schertler, now at the Paul Scherrer Institute in Villigen, Switzerland. "The measurements were all on my grants." The crystals diffracted to a resolution of around 20 ångströms - so low that there was no discernible image. A resolution of about $4 \AA$ is needed to see the organization of individual atoms.

Still, says Kobilka, "it was very exciting. In part it was because I was very naive. I thought we'd be able to get to $3 \AA$ in no time." He finally had the confidence to hire postdocs

\section{"That's what makes scientists go. That moment, when we know we've found a new continent."}

for the crystallography project. In 2005 , he also received a financial lifeline, winning two funding streams from the US National Institutes of Health in Bethesda, Maryland. But frustration followed - the team couldn't get the crystals to grow any bigger or diffract any better. The receptor's changeable activation states and floppy segments - particularly one restless loop on the intracellular side of the receptor - made it very difficult to trap all the proteins in an identical conformation. The team realized that they'd have to do something radical: chop off the loose ends, and either anchor the loop in place with an antibody or replace it altogether with a protein known to crystallize well.

The antibody project, led by postdoc Søren Rasmussen, came together first. As before, they first took the crystals to Schertler, at the ESRF. "It was the greatest thing," says Schertler. "Brian and I and our team were at the synchrotron. We were sitting in front of the machine when the measurements came in. When we first saw the pattern for $3.5 \AA$, everyone in the room jumped up. It was a very happy moment. That's what makes scientists go. That moment, when we know we've found a new continent." The structure, published in Nature ${ }^{1}$, was the second crystal structure of a GPCR, after rhodopsin.

Scientists, however, reserve their accolades for the fusionprotein project, which wasn't far behind. Postdoc Daniel Rosenbaum found that one protein - T4 lysozyme (T4L) - looked promising for fusing to the receptor in place of the loop. And Kobilka had got in touch with Ray Stevens at the Scripps Research Institute in La Jolla, California, and his new postdoc Vadim Cherezov, who had been optimizing a fatty scaffold to lock the membrane proteins in place for crystallization. T4L and the fatty scaffold turned out to be the winning combination. Just days after the Nature paper, Kobilka and Stevens published back-to-back papers in Science ${ }^{2,3}$ that solved the structure of the engineered $\beta_{2} \mathrm{AR}$ to $2.8 \AA$.

The trio of papers marked a milestone in structural biology, and sharply intensified the competition in what was by now a fast and aggressive field. Stevens became one such competitor, and his lab is now powering through further
GPCR structures.

But Kobilka's heart was set on a different goal. The GPCR structures had been snapshots of receptors in an inactive state. To really understand the receptor's workings, researchers needed to see it as it was being activated by a ligand and turning on the $G$ protein. This project was even more technically daunting than the last. The protein complex was too big to hold in the fatty scaffold; the G protein kept falling off; and this time, the extracellular part of the receptor wouldn't sit still for crystallization. "This was difficult enough that I wasn't sure we were ever going to get it," says Kobilka. "I thought it might be my retirement project." He also knew that several other labs, particularly those studying rhodopsin, were breathing down his neck.

Kobilka reached out to all manner of experts for help, including Roger Sunahara, an expert on G proteins at the University of Michigan in Ann Arbor. The various groups developed a detergent for stabilizing the receptor with its G protein; a lipid scaffold that could support the complex; and an antibody that could hold it together. And Rasmussen was relentless, testing thousands upon thousands of crystallization conditions and ways to engineer the protein.

One morning last May, Kobilka took a quick peek down the microscope at Rasmussen's latest effort to produce crystals. "They were already bigger than any other crystals we'd grown of the complex," says Kobilka. "It was extremely exciting. I didn't know if they would diffract well or not, but I had a good feeling." But a planned trip to China meant that he couldn't be there for the first X-ray images. "As soon as we got to the hotel in Beijing, he got online," says Tong Sun. When he found out it was solved, "he was on cloud nine. You could tell he just wanted to go back."

The new picture, solved to a resolution of $3.2 \AA$, reveals a tangled molecular threesome: $\beta_{2} \mathrm{AR}$ with a ligand clasped at one end and the $\mathrm{G}$ protein nested up on the other. "There's definitely been a race, and in my opinion, Kobilka has triumphed," says Chuck Sanders, a structural biologist at Vanderbilt University in Nashville, Tennessee. "Hopefully the field will spread out a little. This complex was the prize, and that's been done now."

Kobilka, of course, diverts credit to his collaborators and the "unsung heroes" of his lab, anxious that everyone should see their names in this story. His allegiance to the receptors is as resolute as ever. "The more we learn" about these proteins, he says, "the more complicated and fascinating they are".

He is already working to understand more of the complications: what the various active states of the receptor look like, why different receptors couple to different $G$ proteins and what happens when different ligands bind to the same receptor. He is also using other techniques, such as electron microscopy and nuclear magnetic resonance, to understand how GPCRs flex and move. "The job isn't done yet," he says.

Maybe not - but few would doubt now that Kobilka will finish it. "Brian ultimately reaches his goals," says Lefkowitz. "Sometimes it takes 15 years, but he gets there."

Lizzie Buchen is a freelance writer based in San Francisco, California.

1. Rasmussen, S. G. F et al. Nature 450, 383-387 (2007),

2. Rosenbaum, D. M. et al. Science 318, 1266-1273 (2007),

3. Cherezov, V. et al. Science 318, 1258-1265 (2007).

4. Rasmussen, S. G. F. et al. Nature 469, 175-180 (2011).

5. Rasmussen, S. G. F. et al. Nature http://dx.doi.org/10.1038/ nature10361 (2011)

6. Dixon, R. A. F. et al. Nature 321, 75-79 (1986)

7. Ghanouni, P. et al. J. Biol. Chem. 276, 24433-24436 (2001).

8. Palczewski, K. et al. Science 289, 739-745 (2000). 